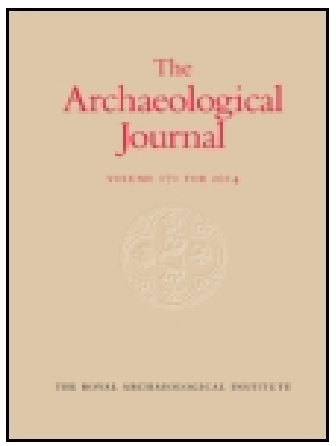

Archaeological Journal

\title{
On the Gad-Whip Service, Rendered at Caistor Church, for Lands at Broughton, Lincolnshire
}

\section{W. S. W.}

To cite this article: W. S. W. (1849) On the Gad-Whip Service, Rendered at Caistor Church, for Lands at Broughton, Lincolnshire, Archaeological Journal, 6:1, 239-248, DOI: 10.1080/00665983.1849.10850735

To link to this article: http://dx.doi.org/10.1080/00665983.1849.10850735

曲 Published online: 10 Jul 2014.

Submit your article to this journal $[\pi$

Q View related articles $\longleftarrow$ 
shape. $^{.}$When I saw the urn, the ashes and half-calcined bones were in it. The lady, to whom the ancient tale ascribes them, was Bronwen, daughter of Llyr Llediaith, (of foreign speech), and sister to Bran the Blessed, as he is styled in the Triads, the father of Caractacus. By the Romance her adventures are connected with Ireland, where she was ill-treated by Matholwch, then ling of that country, in consequence of which she left it, and landing in Wales, the Romance tells us, she looked back upon Ireland, which freshening the memory of the indignity she had met with there, broke her heart. To confirm the fact of the affront given her, one of the Triads (that very ancient and singular. Welsh chronicle by Threes) records it as one of the three mischievous blows (with the palm of the hand) of Britain, viz., the blow of Matholwch the Irishman (Gwyddelian), given to Bronwen, the daughter of Llyr."

In 1821. Bronwen's urn was in the possession of Mr. R. Llwyd, of Chester.' It was subsequently deposited in the British Museum, and by the kindness of Mr. Hawkins, leeper of the antiquities, we are now enabled to give a correct representation of this interesting relic. Its dimensions are as follows. Height, 12 in.; greatest diam., 11 in.; diam. of mouth, 9 in.

In the periodical to which we are indebted for the foregoing account, a curious notice is also preserved of the discovery, in March, 1821, of ten uns at Llysdu, Caernarvonshire, near a supposed Roman way. They lay about a foot beneath the surface, occupying a circular space, about five yards in diameter, which appeared to have been surrounded by a wall. They were of rude fabrication, filled with bones, and in one was a small piece of bronze. Each urn was protected by four upright stones, forming a small cist, with a flat stone on the top. Unfortunately they quickly crumbled to dust, and no portions could be preserved. ${ }^{2}$

A. W.

\section{ON THE GAD-WHIP SERVICE, RENDERED AT CAISTOR CHURCH, FOR LANDS AT BROUGHTON, LINCOLNSHIRE.}

ANY one who has given to the pages of Blount's Ancient Tenures even a cursory attention, must have been amused, not only with the variety, but in some instances with the singularity of the rents and services reserved by our kings and their barons, on granting out lands to tenants when military service or the value of the return was not an object. Of these the services in Grand Serjeanty formed a numerous class, being for the most part those of which we were accustomed to hear when a coronation was about to take place,

8 A figure was given in the CambroBriton, supplied by Mr. John Fenton, partly from his father's sketch, "and from having seen some scores of the same urns, which are uniform in their proportions or shapes, whether found in Wales, Wiltshire, or elsewhere."

"Sec the "Three Fatal Slaps." CambroBriton, vol. ii., p. 10.

1 Note in Cambro-Briton, vol. ii., p. 371.

2 Cambro-Briton, vol. ii., p. 430 . 
and the tenants claimed to perform the services by which they held. They contributed to the state and magnificence of the ceremony, and the gratification of the attendance, and the piece of plate or other valuable article which fell to the tenant's lot as his fee, made the service to be regarded by him as more a benefit than a burden. Passing by these, and also the services in Petty Serjeanty, where the tenant had to render to the king something in the nature of arms or armour, or at least relating to war, there were numerous instances among the tenures in socage, both of the king and others, in which the services reserved were very fanciful, and a few in which they seem whimsical; such as lifting up the right hand towards the king on Christmas day wherever he might be in England; hunting the king's wild greese (swine) on a certain day; gathering wool off whitethorns for the queen; holding the lord's stirrup on certain occasions; and what, let us hope, was not very rigorously exacted, rendering a snowball at Midsummer, and a red rose at Christmas. One man held by saying a Paternoster daily for the king's soul : another by saying five Paternosters daily for the king's ancestors; from which services these tenants may be assumed to have acquired their surname of Paternoster. A Percy, a scion of the noble house of Louvain, held property at Levington, Yorkshire, by a service no doubt far more agreeable than most others, viz., by repairing to Skelton Castle on Christmas day, and leading the lady of the castle from her chamber to chapel, and thence to her chamber, and afterwards dining with her before he departed.

But one of the most extraordinary tenures escaped the notice of the assiduous collector above named, and his editor, Mr. J. Beckwith, though the service has been only recently discontinued. The earliest mention I have found of it is in Gough's edition of Camden's Britannia, vol. ii., p. 276, on the authority of a communication made to the Spalding Society. There is also an account of it in the "Gentleman's Magazine" for 1799, taken from the "British Critic" of the same year, and of this the editor of the third and last edition of Blount's Ancient Tenures has availed himself; but for the more full and correct account which I am enabled to give, the Institute is indebted to Mr. Moore, of Lincoln, who has lately brought the subject before the Society in a communication read at one of our monthly meetings. The service was 
rendered at Caistor Church, Lincolnshire ; the property held by it, which is said to have comprised the Manor of Broughton and 2200 acres of land, lies in the parish of Broughton, near Brigg, in the same county, about twelve miles from Caistor, and was sold by auction in 1845. I cannot do better than state the ceremony from the Particulars of Sale circulated in 1845, as the sellers had the best means of ascertaining the facts, and were concerned to set them forth correctly :

"This estate is held subject to the performance, on Palm-Sunday in every year, of the ceremony of cracking a whip in Caistor Church, in the said county of Lincoln, which has been regularly and duly performed on Palm Sunday, from time immemorial, in the following manner :

"The whip is talsen every Palm-Sunday by a man from Broughton to the parish of Caistor, who, while the minister is reading the first lesson, cracks it three distinct times in the Church Porch, then folds it neatly up, and retires to a seat. At the commencement of the second lesson, he approaches the minister, and kneeling opposite to him, with the whip in his hand, and purse at the end of it, held perpendicularly over his head, waives it thrice, and continues it in a steadfast position throughout the whole of the chapter. The ceremony is then concluded.

"The whip has a leathern purse tied at the end of it, which ought to contain thirty pieces of silver, said to represent, according to seripture, "the price of blood.' Four pieces of Weechelm Tree, of different lengths, are affixed to the stock, denoting the different gospels of the holy Evangelists. The three distinct cracks are typical of St. Peter's denial of his Lord and Master three times; and the waiving it over the minister's head, as an intended homage to the blessed Trinity."

In addition to what is contained in the foregoing extract, Mr. Moore furnished the following information respecting this service and the estate for which it was rendered:

"I have never been able to trace this custom to its source. It would appear to have prevailed in very primitive times, and yet the circumstance of the custom requiring the more essential part of the ceremony to be performed during the reading of the second lesson, is scarcely reconcileable with this idea; but I am induced to think that the custom prevailed long before our present ritual existed, and that it has in this respect been accommodated to the changes which Time has effected in the services of the Church. Unfortunately the title-deeds do not contain the slightest reference to the custom. I have no means of tracing the title beyond 1075 . The parish of Broughton is a very large one, and anterior to 1675 belonged, with some small exceptions, to the Añderson family; but whether Stephen Anderson, the then owner of the manor, and the 2200 acres of land sold in 1845, was owner of the other part of Broughton, which has long been in the possession of Lord Yarborough's ancestors, I cannot say. A partition of the property appears to have been made between two coheiresses; and the manor and 2200 acres being settled in 1772 by Sir Stephen Anderson 
of Eyeworth, on his niece, Frances Elizabeth Stephens, and her issue; upon her death it became the property of her son, Ellys Anderson Stephens, who died in 1844, leaving four daughters and coheiresses; and who, in 1845, sold the property to a client of mine, Mr. John Coupland, and who afterwards sold the manor, and about 600 acres to Lord Yarborough, 982 acres to myself, and other portions to different purchasers, reserving to himself about 200 acres.

"I cannot make out when this partition (above alluded to) took place. The deed or will by which it was effected would probably refer to the custom and provide for the performance of it; but there is no document with the title-deeds tending to show whether the custom was due only in respect of the manor, and 2200 acres, or in respect of Lord Yarborough's portion of the parish as well. The fact of a partition having taken place rests rather upon tradition than evidence; but, supposing it, as $I$ do, to be a fact, it seems strange that the title-deeds should be silent as to the obligation imposed upon the owner of the manor, to perform the service by which the whole property was held. The manor and estate sold in 1845 , were of the tenure of ancient demesne; a tenure which is very rare at this time of day, at least in this part of the world. Probably a reference to Lord Yarborough's title-deeds would clear up the mystery; or Sir Charles Anderson may have the means of doing so.

"I may also refer to Sir Culling Eardley, as possibly in a condition to throw some light on the subject; for it was to him and his ancestors, as lords of the manor of Hundon in Caistor, to whom this service was due, and for whose use the whip was deposited, after the service, in the pew of Caistor Church, belonging to the lord of the manor of Hundon."

From the preceding information communicated by $\mathrm{Mr}$. Moore, the manor of Broughton, and about 2200 acres of land in that parish, appear to have been ancient demesne, and held of the manor of Hundon in Caistor, by the service specified in the particulars of sale; and it is supposed that the rest of the parish was formerly held with it by the same tenure and service. The fact, however, of the tenure being ancient demesne does not clearly appear in Domesday, which is the proper evidence of that tenure. Under the head of "Terra Regis," in Lincolnshire, fo. 338. b., occurs the following entry :-

“Manerium ? In Castre et IJumendone habuit comes Morcar III

et Burgus. J carucatas terræ ad geldam. Terra ad vi carucas. Ibi habet Rex in dominio I carucatam et Xx villanos et XII sochmannos cum tribus carucis. Ibi Ecclesia et presbyter quos episcopus Lincolniæ clamat. Ibi IIII molendina XIII solidorum et IIII denariorum et $\mathrm{IX}$ acræ prati. Tempore Regis Edwardi valebant xxx libras modo $\mathrm{I}$ libras. Ad hujus manerii aulam pertinent Catenai et Usun IIII carucatæ terræ ad geldam. Terra ad virr carucas ibi in dominio II carucæ et $\mathrm{xx}$ villani et $\mathrm{xv}$ sochmanni et $\mathrm{x}$ bordarii habentes $\mathrm{Ix}$ carucas. Ibi ccc et $\mathrm{Lx}$ acræ prati. Ad eundem manerium jacet Hundredi soca." 
Here we have mention made of Caistor and Hundon, but nothing of Broughton; nor can I find the last in any other part of Domesday. Catanai and Usun are probably Cadney and Howsham, which are much nearer to Caistor. Seeing the extent of Broughton and its distance from Hundon, I can hardly think it is comprised in the above extract as part of the carucates of land there mentioned. Assuming, however, that the manor of Broughton and the 2200 acres were ancient demesne (which they may have been, notwithstanding it does not clearly appear in Domesday), that circumstance points to an Anglo-Saxon origin for this custom ; since lands held by that tenure were part of the demesnes of our Anglo-Saxon kings, or at least of the last of them, Edward the Confessor: and the original service, however it may have been since varied, was, I think, certainly reserved at an early period, and probably before the Conquest.

It was a rare occurrence for any large quantity of land to be granted out at a single rent, unless as parcel of a manor ; and it is very improbable that the 2200 acres should have been granted to be held by so singular a reservation as this, if they did not form part of the manor of Broughton. And if that were the case, I am not much surprised at the title deeds not noticing this peculiarity of the tenure; for, even had there been a partition as Mr. Moore supposes, I do not think it very likely there would at that time have been any attempt to make an arrangement for the performance of the service, as the party who took the manor in its reduced condition would have been regarded as the person to perform it, as a matter of course, and for his own interest; and no effectual means could have been devised for averting the consequences of his failing to do so. If there be more than one manor in the parish of Broughton (no uncommon case), Lord Yarborough's ownership of the rest of the parish may be accounted for, without the necessity of supposing a partition to have taken place. The court rolls, rental or custumal, of the Manor of Hundon would be most likely to contain some notices of this singular reservation.

All the versions that I have seen of this custom, favour the opinion that it had some reference to the subject of the second lesson for Palm Sunday, which is the 26th chapter of St. Matthew ; and if so, it would seem likely to follow, that the principal part of the ceremony always took place at the 
reading of that chapter; but in that case it has clearly undergone some change, because, until the last revision of the Book of Common Prayer, there was no proper second lesson for the morning of Palm Sunday; but the 26th chapter of St. Matthew was part of the Gospel for that day, and had been so from Anglo-Saxon times.

Perhaps the better opinion is, that the custom, recently discontinued, had been so varied from time to time as to have borne at last little resemblance to what originally took place. I do not suppose that in its commencement it was regarded as at all irreverent, or was intended to be otherwise than most decorous, according to the ideas of a semibarbarous age. What it really was at first I fear it may now be impossible to discover or conjecture. The explanation suggested in the particulars of sale appears to me too much in accordance with modern notions, to be altogether correct. Some allege a tradition, that it was a self-inflicted penance by a former owner of the Broughton estate, for killing a boy with such a whip. I see nothing in the ceremony to countenance that view of it; nor does it seem in itself probable. May not this notion of penance have been suggested by the account given of the supposed origin of a curious custom, which exists at Whitby, of making, what is familiarly called, "the Penny Hedge," on Ascension-day, and consists now of constructing a slight fence on the shore, below high water mark, with a few stakes, strutts, and wattles (locally termed yadders or yethers). The particulars of this singular service, rendered by a tenant to his lord, will be found in Charlton's History of Whitby.

From the Whip, which had so prominent a part in this matter, some have been disposed to derive the distinctive name of Thong, formerly affixed to Caistor, when it was called Thong Caistor, or Thong Castle. This is at least as probable as the tradition which would account for that name, by alleging that Caistor, like Carthage, was built on as much ground as an ox-hide cut into thongs would encompass.

Whatever may have led to this strange reservation, or whatever may have been the origin of the old name of Caistor, I cannot but think that the custom in question, at its commencement, had reference to some of the various ceremonies which took place on Palm Sunday, difficult as it is to reconcile the recent usage with them entirely. The probability 


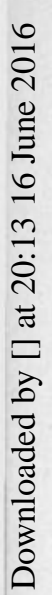

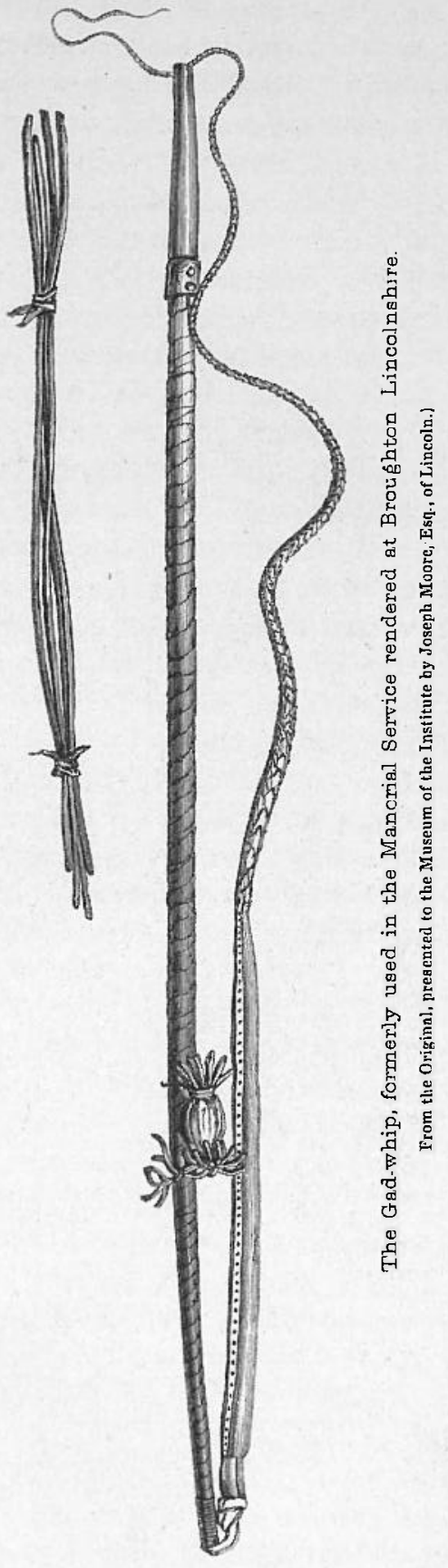


of this will be rendered more apparent, I hope, if we recur to the details of it. The man who came to render the service brought with him a whip, resembling a cart-whip, but locally called a Gad-whip, or Gad (of which a few words presently), a small purse of leather (the account in the "Gentleman's Magazine" says it was of green silk), containing some silver (qy. thirty silver pennies originally), and tied at the upper end of the whip, and four pieces (slender rods) of wych-elm, of different lengths, varying from 3 feet 2 inches to 2 feet 7 inches, or thereabouts, which were bound to the handle of the whip. We are indebted to Mr. Moore for one of these Gads, which, with its appendages, he very obligingly presented to the Institute during the meeting at Lincoln, and of which a representation is here given. (See cut.) It is not an ordinary whip, but of rude workmanship, and made in a peculiar manner for the occasion, there having been a new one of the same kind every year. ${ }^{1}$ The handle, which is of ash, bound round with white leather to within $8 \frac{1}{2}$ inches of the butt, is 5 feet 8 inches long, and tapered off somewhat obtusely at the lower end, but without any metal point. ${ }^{2}$ The lash is of white leather, probably cow-hide, and is 7 feet 9 inches long, the upper part for 30 inches not being braided. Whether it was once both a goad and whip, or denominated a Gad by analogy, because, as a whip, it answered the purpose of a goad for driving animals, I must leave the curious to determine for themselves. ${ }^{3}$

\footnotetext{
1 Another of these whips was exhibited in the museum formed during the Meeting of the Institute, with the broken fragment of a third. These relics of a very singular custom were regarded with much interest, and our best thanks are due to Mr. Moore, for depositing one in the Museum of the Institute.

${ }^{2}$ It appears probable that this might have served as a goad, in the original intention of the whip : and this supposition would certainly supply a satisfactory explanation of the name-A. W.

3 Anglo-Sax. Gad-stimulus, the point of a weapon. " A gad-ger'usa." (Catholicon Materna Lingua, dated 1483. MS. Engl.-Latin Dictionary in Lord Monson's Library, compiled in Lincolnshire, as is supposed.) The Promptorium Parvulorum, compiled at Lynn, in Norfolk, in the 15th century, gives "Gad or gode, gerusa, scutica." (Various readings - gadde, gaade, gadde or whyppe. This last is as the word stands in Pynson's printed edition.) 'The VOL. VI.
}

Promptorium also gives "Gad (or rodde, Pynson) to mete with londe, Decempeda, pertica"-"Gode, supra in Gade." "Mastigia, a gadde." (Ortus Vocabulorum.-) Palsgrave gives, in his Eclaircissement de la langue Francoyse,_- "Gadde for oxen, esguillom." In the Craven dialect-" Gad, a long stick, also a tall slender person; the gads are sometimes sharpened with iron." In Brockett's North Country Dialect-" "Gad, gaed, or ged, a fishing rod. a wand, a long stick with a pike at the end, formerly used to drive oxen when they were employed as beasts of draught." It is a term still used for a cartman's whip :

"He criyt, Theyff ! call all ! call all ! And he then lete the gad-wand fall."

The Bruce.

"Gad, a hedge-stake or stout stick."Barnes" Dorset Dialect-" Ane rod is ane staffe or gade of tymmer quhairwith land is measured." Skene v. Parlicata. J. K., in the New English Dictionary, 1759, 
Now, as to what was done: the bearer of the whip so furnished, before entering the church, cracked it thrice in the porch, at the reading of the First Lesson ; at the reading of the Second Lesson he knelt before the minister, and, after waiving the whip, with the purse attached, over the minister's head thrice, he held it steadily over his (the minister's) head while he read the rest of the Lesson, and afterwards he deposited the whip, \&c., in the seat of the Lord of the Manor of Hundon. In this I apprehend there is little in common with what took place under the ancient ritual; and, as the gospel was hardly read from so high an elevation as the desk, the whip may have formerly been shorter. Palm Sunday at that time was remarkable for some very popular and peculiar ceremonies, both in the churches and out of doors. They differed at different places. At an office before mass, the hallowing of the palms was effected, for which, as real palms could not be obtained, branches or rods of willow, box, and other trees, were substituted, and, when hallowed, were called palms, whatever they might be. Then there was a procession, not only about the church, but through the town or village, the host, or sometimes an image, being carried on an ass, or on a wooden figure of one, followed by the priests and others bearing palms and singing, while boughs and garments were strewed in the road before the ass, in commemoration of our Saviour's triumphant entry into Jerusalem. Little crosses made of the consecrated palm were inclosed in purses as a protection against the evil one, and also against storms. There were also certain performances, in which an angel and a prophet were among other dramatis personce; but the particulars of these I have not met with. May not the whip, the purse, and the four pieces of wych-elm, have been originally presented to the priest for the purpose of being used in some manner on Palm Sunday? The whip to drive the ass, and to repress the too eager curiosity of the thoughtless and irreverent portions of the crowd, though of late somewhat inconveniently long; the purse for receiving a

gives, " a gad, a measure of nine or ten feet." -Nares, v. Gacl, cites Hoole's A riosto, x. 73 , where " $a$ slender gad" is mentioned, carried by horsemen lightly armed ("with jacks"):-

"They run on horseback with a slender. gad,

[long."

And like a speare, but that it is more

In the Scottish dialect Gad is a fishingrod. Douglas, in his translation of Virgil, speaks of "gadwandes" for driving cattle. Barct, in his Alvearie, 1530 , gives both" a gadde or goade, stimulus, pertica stimulata, esguillon" and "a gadde or whippe, flagellum, fouet, ou escourgec."-A. W. 
piece or cross of consecrated palm for the Lord of Hundon ; the thirty silver pennies (if contained in it) as an allusion to the price of the betrayal, and intended, perhaps, as the priest's fee or an offering; and the four rods of wych elm to be hallowed for palms, to be borne by the lord and some of his family,-- for great importance was attached to bearing the palms in the procession? There would be nothing inconsistent with this supposition in the whip, as well as the purse and palms, being afterwards delivered to the Lord of the Manor of Hundon, as evidence of the tenure; nor in the money also being handed over to him, if it were not the priest's fee or an offering. Perhaps, if we knew more of the practices of the Church in Anglo-Saxon times, we should be able to find a more satisfactory explanation of these things in relation to the proceedings of the day. There is, however, a difficulty in reconciling what has been said of them with the opinion that this ceremony always took place at the reading of the twenty-sixth chapter of St. Matthew; because, since in the ancient ritual that was part of the Gospel at the Mass, the presentation of the whip, \&c., would have taken place after the palms had been blest, and the procession was over. It is true the benediction of the palms is sometimes mentioned as following the Gospel, but it was the Gospel of that particular office, which, according to the present Roman Ritual, was the first nine verses of the twenty-first chapter of St. Matthew, the portion of the Gospel history which the procession was intended to commemorate. Is it not likely that the ceremony in question originally took place at this Gospel ; that at the Reformation, when the office for hallowing the palms and the procession were abolished, it was transferred to the Gospel of the day, which consisted of the twenty-sixth and twenty-seventh chapters; and that when the former of these became the Second Lesson, the ceremony which had become associated with it was performed, as it has recently been, at the time of reading that Lesson?

If the ceremony be regarded as referring to the subject of the twenty-sixth chapter of St. Matthew, the whip might represent the scourge, and the purse and thirty silver pennies be intended for the purse borne by Judas, and the price of the betrayal ; but then it is not easy to assign any meaning to the pieces of wych-elm, and the purse was a very small one to represent that borne by Judas. As to the three 
cracks of the whip in the porch, these may probably have referred to the denials of St. Peter, to whom, with St. Paul, the church is dedicated; and it may be observed that, as those denials occurred out of the Sanhedrim or council, this may have been signified by the porch being chosen for the performance of this part of the ceremony. I see nothing in the First Lesson of the day to which it could possibly allude, nor in the Lesson of the ancient ritual for the benediction of the palms (Exodus, xv., 27, and xvi., 1-7), according to the Roman Missal. It is hard to conjecture at what part of the ancient office for Palm Sunday this commencement of the ceremony could have taken place.

Upon the whole, my conviction is, that very great changes were made from time to time in the mode of rendering the service by which the Broughton estate was held, until it had little in common with the original, and as these ought to have been matters of arrangement between the lord and the tenant, if the documents relating to the Manor of Hundon extend sufficiently far back, it is very likely something might be found in them respecting the alterations which took place at the Reformation, and also in 1662, when the Book of Common Prayer was last revised.

Every one must approve of the discontinuance of this singular interruption of Divine service; but it may not be without interest to the members of the Institute to have so curious a remnant of ancient usage brought before them; and, as one obscure matter often throws light on another, when they are brought into comparison, so this may happen presently to illustrate, or to be explained by some dark passage, with which it has not yet been compared.

W. S. W.

NOTICES OF A REMARKABLE DISCOVERY OF SILVER ORNAMENTS IN A TUMULUS AT LARGO, IN FIFESHIRE.

COMMUNICATED BY ROBERT DUNDAS, ESQ., OF ARNISTON.

Is a former Memoir on Ancient Personal Ornaments found in the British Islands, the readers of the Journal have been made acquainted with an interesting discovery of gold armillæ, found on the shore of Fifeshire, in 1848, and laid before the 